\section{Synthesis and Antimetastatic Activity of 6-Trichloroacetamido and 6-Guanidino Analogues of Siastatin B}

\section{Takahiko Satoh, Yoshio Nishimura, *} SHINICHI KONDO and TOMIO TAKEUCHI

Institute of Microbial Chemistry, 3-14-23 Kamiosaki, Shinagawa-ku, Tokyo 141, Japan

\section{Masayuki Azetaka, Harumi Fukuyasu, YuMIKo IIzUKa, SHOKICHI OHUCHI and Seiji Shibahara}

Pharmaceutical Research Center, Meiji Seika Kaisha, Ltd., 760 Morooka-cho, Kohoku-ku, Yokohama 222, Japan

(Received for publication October 13, 1995)

Current studies $^{1 \sim 5)}$ have provided considerable evidence of increase of $\beta$-glucuronidase activity in human tumors and suggested that $\beta$-glucuronidase plays a key role in degradation of basement membranes during metastasis of the tumor cells, and showed that $\beta$ glucuronidase inhibitors inhibit tumor-cell metastasis.

In the course of our studies ${ }^{6 \sim 16)}$ of new drugs for tumor metastasis based on siastatin B (1), ${ }^{17)}$ we showed that synthetic $(3 S, 4 S, 5 R, 6 R)$-6-(trifluoroacetamido)-4,5dihydroxypiperidine-3-carboxylic acid (2) and $(3 R, 4 R$, $5 R, 6 R$ )-6-(trifluoroacetamido)-3,4,5-trihydroxypiperidine-3-carboxylic acid (3) have the marked inhibitory activity against $\beta$-glucuronidase. ${ }^{15)}$ They were also found to show the inhibition of highly metastatic B16 variant (B16 BL6) and Lewis lung carcinoma (3LL) cell invasion through reconstituted basement membranes and the potent suppression of pulmonary metastasis of B16 BL6 and $3 \mathrm{LL}$ cells in mice. ${ }^{15,16)}$ These results prompted us

to further modify the amide function at C-6 of 1 focused on the glucuronidase inhibition and suppression of lung metastasis of tumor cell. Here, we wish to report the syntheses of $(3 S, 4 S, 5 R, 6 R)-6$-(trichloroacetamido) and ( $3 S, 4 S, 5 R, 6 R)$-6-guanidino-4,5-dihydroxypiperidine-3carboxylic acids (4 and 5 ) having inhibitory activity for $\beta$-glucuronidase and pulmonary metastasis of B16 BL6.

\title{
Chemistry
}

The potent inhibition of $\mathbf{2}$ and $\mathbf{3}$ for $\beta$-glucuronidase suggest that the trifluoroacetamide function may play an important role in the strong binding of $1-N$-iminosugar to $\beta$-glucuronidase. In order to examine the neighboring participation of amide group of $\mathbf{1}$ in $\beta$-glucuronidase inhibition, replacement of acetamide function by trichloroacetamide and guanidino ones are next undertaken.

Fig. 1. Structures of siastatin B (1) and its 6-trifluoroacetamido analogues $\mathbf{2}$ and $\mathbf{3}$.

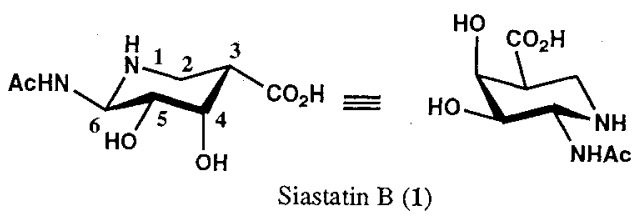

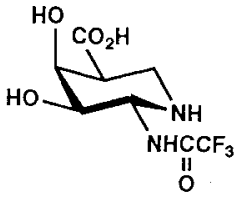

2

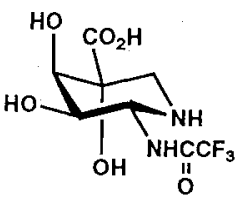

3

Scheme 1. Synthesis of 6-trichloroacetamido and 6-guanidino analogues of siastatin B.

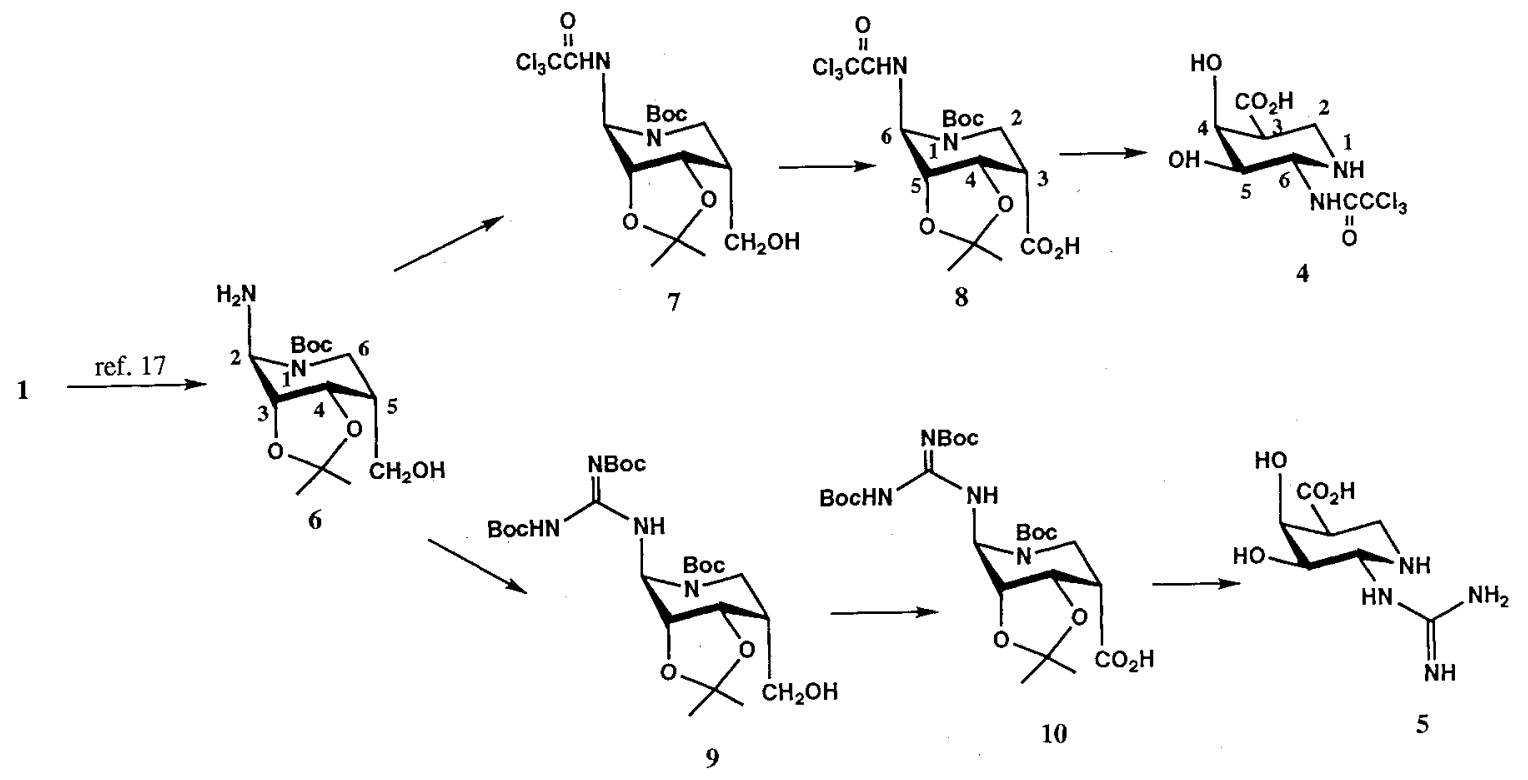


The starting $(2 S, 3 R, 4 S, 5 R)$-2-amino- $N$-(tert-butoxycarbonyl)-5-hydroxymethyl-3,4-O-isopropylidene-3,4piperidinediol (6) was easily obtained from 1 by the method developed by us. ${ }^{18)}$ Trichloroacetylation of the amino-alcohol 6 with trichloroacetyl chloride gave the trichloroacetamide 7 in a good yield. Oxidation of the hydroxymethyl group to the carboxylic acid was best achieved by ruthenium tetraoxide catalyzed oxidation in a solvent system of $\mathrm{CH}_{3} \mathrm{CN} / \mathrm{CCl}_{4} / \mathrm{H}_{2} \mathrm{O}$ developed by SHARPLESs et al. ${ }^{19)}$ Thus obtained compound $\mathbf{8}$ was smoothly converted into 4 by removal of the protecting groups with acid. On the other hand, treatment of $\mathbf{6}$ with $N, N^{\prime}$-di-(tert-butoxycarbonyl)thiourea in the presence of mercury (II) chloride ${ }^{20)}$ afforded the guanidino compound 9 in an excellent yield. Compound 9 was straightforwardly transformed into $\mathbf{5}$ by the similar method described above.

\section{Biological Activities}

As expected, both 4 and 5 inhibited $\beta$-glucuronidase from bovine liver shown in Table 1. Compound $\mathbf{4}$ as well as 5, also showed weak inhibitory activity against $\beta$-glucosidase (almonds), while they did not inhibit any other glycosidases (bakers yeast $\alpha$-glucosidase, Jack beans $\alpha$-mannosidase, snail $\beta$-mannosidase, $E$. coli $\alpha$ - and $\beta$-galactosidase, bovine kidney $\beta$ - $N$-acetylglucosaminidase, chicken liver $\alpha$ - $N$-acetylgalactosidase; $\mathrm{IC}_{50}>100$ $\mu \mathrm{g} / \mathrm{ml}$ ). Lung colonization after intravenous transplantation of the highly metastatic variants of B16 melanoma $(\mathrm{B} 16 \mathrm{BL} 6)^{21,22)}$ was suppressed dose-dependently by in

Table 1. $\mathrm{IC}_{50}(\mu \mathrm{M})$ of siastatin $\mathrm{B}(\mathbf{1})$, and its analogues $\mathbf{4}$ and $\mathbf{5}$ against glycosidases.

\begin{tabular}{ccc}
\hline Compound & $\begin{array}{c}\beta \text {-Glucosidase } \\
\text { (almond) }\end{array}$ & $\begin{array}{c}\beta \text {-Glucuronidase } \\
\text { (bovine liver) }\end{array}$ \\
\hline 1 & $>440$ & 16 \\
4 & 137 & 4.7 \\
5 & 96 & 4.1 \\
\hline
\end{tabular}

vivo pretreatment with $\mathbf{4}$ and $\mathbf{5}$ as shown in Table 2 . Compounds 4 and 5 had no significant effects on cell growth at the concentrations used in this study (data not shown). Tables 1 and 2 show that the inhibitory activity for B16 BL6 metastasis is proportional to the inhibitory activity against $\beta$-glucuronidase. On the other hand, NAKAJIMA et $a l^{3,23,24)}$ proved that heparanase (endo- $\beta$-glucuronidase) activity correlates with the lung colonization abilities of murine B16 melanoma cells by extracellular matrix degradation. These facts suggest that $\mathbf{4}$ and $\mathbf{5}$ as glucuronidase inhibitors inhibit extracellular matrix degradation and/or modify cell-surface glycoconjugate of B16 BL6 cells, resulting in the inhibition observed of experimental pulmonary metastasis of B16 BL6. These facts indicate that the antimetastatic effect of 4 and 5 may be due to its antiinvasive rather than antiproliferative activities. The present study promise a way to inhibit tumor metastasis through a better understanding of biochemical processes. Further investigation of $\beta$-glucuronidase inhibitors for inhibition of tumor metastasis is in progress.

\section{Experimental}

General Methods

Melting points were determined with a Yanagimoto apparatus and were uncorrected. IR spectra were determined on a Hitachi Model 260-10 spectrophotometer. Optical rotations were measured with a Perkin-Elmer Model 241 polarimeter. ${ }^{1} \mathrm{H}$ NMR spectra were recorded with a JEOL JNM EX270 spectrometer. Chemical shifts are expressed in $\delta$ values (ppm) with tetramethylsilane as an internal standard. MS spectra were taken by a JEOL JMS-SX102 in the FAB mode.

Enzyme Inhibition Assay

$\overline{\alpha-G l u c o s i d a s e}(\text { yeast })^{25)}$ and $\beta$-glucuronidase (bovine liver) ${ }^{26)}$ assays were evaluated by methods described in references.

Table 2. Inhibitory effect of $\mathbf{4}$ and $\mathbf{5}$ on the experimental metastasis of B16 BL6 cells in mice.

\begin{tabular}{|c|c|c|c|c|c|}
\hline \multirow[b]{2}{*}{ Compound } & \multirow{2}{*}{$\begin{array}{l}\text { Dose } \\
(\mu \mathrm{M})\end{array}$} & \multirow{2}{*}{$\begin{array}{l}\text { No. of cells } \\
(\mathrm{ml})\end{array}$} & \multicolumn{2}{|c|}{ No. of lung metastasis } & \multirow{2}{*}{$\begin{array}{l}\text { Inhibition of } \\
\text { metastasis (\%) }\end{array}$} \\
\hline & & & (Mean \pm SD) & (Range) & \\
\hline None & - & $1.3 \times 10^{7}$ & $90.0 \pm 33.3$ & $142-53$ & 0 \\
\hline \multirow[t]{4}{*}{4} & 9 & $1.2 \times 10^{7}$ & $91.0 \pm 33.4$ & $147-64$ & 0 \\
\hline & 31 & $1.4 \times 10^{7}$ & $66.6 \pm 17.5$ & $82-41$ & 26 \\
\hline & 93 & $1.0 \times 10^{7}$ & $63.4 \pm 18.6$ & $93-45$ & 29.6 \\
\hline & 156 & $1.2 \times 10^{7}$ & $29.4 \pm 20.4$ & $55-3$ & $67.3^{*}$ \\
\hline \multirow[t]{4}{*}{5} & 14 & $1.3 \times 10^{7}$ & $69.8 \pm 11.1$ & $79-51$ & 22.4 \\
\hline & 46 & $1.3 \times 10^{7}$ & $36.8 \pm 7.0$ & $45-27$ & $59.1^{*}$ \\
\hline & 137 & $1.1 \times 10^{7}$ & $23.2 \pm 10.1$ & $37-10$ & $74.2^{*}$ \\
\hline & 229 & $1.2 \times 10^{7}$ & $11.6 \pm 7.2$ & $19-0$ & $87.1^{* *}$ \\
\hline
\end{tabular}

* and **, $P<0.01$ and $P<0.001$, respectively. 
Experimental Metastasis Assay ${ }^{21,22)}$

The highly metastatic melanoma B16 (B16 BL6) cells $\left(3 \times 10^{5}\right.$ cells $)$ were cultured in DulBecco's modified EAGLE's medium supplemented with fetal bovine serum under $5 \% \mathrm{CO}_{2}$ at $37^{\circ} \mathrm{C}$ for 24 hours. Cells were incubated with (or without) each test compound under the same condition for 72 hours. After treatment with $0.05 \%$ trypsin and $0.02 \%$ EDTA soln, a cell suspension containing $1.0 \sim 1.4 \times 10^{7}$ cells in $1 \mathrm{ml}$ of divalent cation-free DULBECCo's phosphate-buffered saline was prepared. Cells in $0.1 \mathrm{ml}$ were injected intravenously into the tail vein of each mouse (male $\mathrm{BDF}_{1}, 7$ weeks old). Fourteen days later, after tumor cell implantation, the mice were autopsied. The number of pulmonaty tumor nodules was counted. Inhibition (\%) of metastasis was calculated from the ratio of tumor nodules in treated and control experiments.

$(2 S, 3 R, 4 S, 5 R)-N$-(tert-Butoxycarbonyl)-2-(trichloroacetamido)-5-hydroxymethyl-3,4-O-isopropylidene-3,4piperidinediol (7)

To a soln of $6(124 \mathrm{mg})$ in dichloromethane $(2.5 \mathrm{ml})$ were added pyridine $(0.13 \mathrm{ml})$ and trichloroacetyl chloride $(0.1 \mathrm{ml})$ at $0^{\circ} \mathrm{C}$, and the mixture was stirred at the same temperature for 10 minutes. After dilution with chloroform, the soln was washed with satd aq $\mathrm{NaHCO}_{3}$ soln and $\mathrm{H}_{2} \mathrm{O}$, dried over $\mathrm{MgSO}_{4}$, and filtered. Evaporation of the filtrate gave a pale yellow solid. The solid was dissolved in a satd methanolic $\mathrm{K}_{2} \mathrm{CO}_{3}$ soln $(3 \mathrm{ml})$. After being stirred at room temperature for 10 minutes, evaporation of the solvent gave a solid. The solid was dissolved in chloroform, and the soln was washed with satd aq $\mathrm{NH}_{4} \mathrm{Cl}$ soln, dried over $\mathrm{MgSO}_{4}$, and filtered. Evaporation of the solvent gave a solid, which was subjected to column chromatography on silica gel. Elution with a mixture of toluene - acetone $(5: 1)$ gave $7(162 \mathrm{mg}, 88 \%)$ as a colorless foam: $[\alpha]_{\mathrm{D}}^{25}+16.8^{\circ}(c$ $3.8, \mathrm{MeOH})$; IR $\left(\mathrm{CHCl}_{3}\right) 3420,2980,2930,2900,1720$, $1700,1490,1460,1395,1385,1370,1360,1325,1280(\mathrm{sh})$, $1260,1170,1140,1115,1070,1060,1005 \mathrm{~cm}^{-1} ;{ }^{1} \mathrm{H}$ NMR $\left(\mathrm{CD}_{3} \mathrm{OD}, 40^{\circ} \mathrm{C}\right) \delta 1.36(3 \mathrm{H}, \mathrm{s}$, isopropylidene $), 1.48(12 \mathrm{H}$, $\mathrm{s}$, isopropylidene and $\left.\mathrm{NCOOC}\left(\mathrm{CH}_{3}\right)_{3}\right), 1.95(1 \mathrm{H}, \mathrm{t}$, $J=5.6 \mathrm{~Hz},-\mathrm{OH}), 2.01(1 \mathrm{H}$, broad $\mathrm{m}, 5-\mathrm{H}), 3.16(1 \mathrm{H}, \mathrm{t}$, $J=12.2 \mathrm{~Hz}, 6-\mathrm{Hax}), 3.59(1 \mathrm{H}$, dd, $J=4.4$ and $12.2 \mathrm{~Hz}$, $6-\mathrm{Heq}), 3.79\left(2 \mathrm{H}, \mathrm{t}, J=5.6 \mathrm{~Hz},-\mathrm{CH}_{2} \mathrm{OH}\right), 4.58(1 \mathrm{H}, \mathrm{dd}$, $J=2.4$ and $7.3 \mathrm{~Hz}, 3-\mathrm{H}), 4.62(1 \mathrm{H}, \mathrm{dd}, J=2.0$ and $7.3 \mathrm{~Hz}$, $4-\mathrm{H}), 5.73(1 \mathrm{H}$, broad $\mathrm{s}, 2-\mathrm{H})$ and $6.81(1 \mathrm{H}$, broad $\mathrm{s}$, -NHCO-). Anal. Calcd for $\mathrm{C}_{16} \mathrm{H}_{25} \mathrm{Cl}_{3} \mathrm{~N}_{2} \mathrm{O}_{6}$ : C 42.92, H 5.63, N 6.26. Found: C 42.37, H 5.61, N 6.14.

(3S,4S,5R,6R)- $N$-(tert-Butoxycarbonyl)-6-(trichloroacetamido)-4,5-dihydroxy-4,5-O-isopropylidenepiperidine-3-carboxylic Acid (8)

To a soln of $7(152 \mathrm{mg})$ in a mixture of $\mathrm{CCl}_{4}(2 \mathrm{ml})$ and $\mathrm{CH}_{3} \mathrm{CN}(2 \mathrm{ml})$ were added a soln of $\mathrm{NaIO}_{4}(218 \mathrm{mg})$ in water $(3 \mathrm{ml})$ and $\mathrm{RuO}_{2}(8 \mathrm{mg})$, and the mixture was vigorously stirred at room temperature for 30 minutes. The phases were separated. The aq phase was extracted three times with EtOAc. To the combined organic extracts was added 2-propanol $(0.5 \mathrm{ml})$, and the mixture was stirred at room temperature for 1 hour. After filtration off the precipitates, the filtrate was washed with water, dried over $\mathrm{MgSO}_{4}$, and filtered. Evaporation of the filtrate gave a solid, which was chromatographed on silica gel. Elution with a mixture of $\mathrm{CHCl}_{3}-\mathrm{MeOH}$ concd aq ammonia $(50: 10: 1)$ gave an amorph solid of $\left.8(119 \mathrm{mg}, 76 \%):[\alpha]_{\mathrm{D}}^{24}+3.6^{\circ}(c) 0.87, \mathrm{MeOH}\right)$; IR $\left(\mathrm{CHCl}_{3}\right) 3425,2980,2940,1720,1695,1515,1485$, $1465,1400,1375,1350,1330,1260,1220,1175,1105$, $1070,1000 \mathrm{~cm}^{-1} ;{ }^{1} \mathrm{H}$ NMR $\left(\mathrm{CD}_{3} \mathrm{OD}, 40^{\circ} \mathrm{C}\right) \delta 1.35$ and $1.41(3 \mathrm{H}$, each $\mathrm{s}$, isopropylidene), $1.48(9 \mathrm{H}, \mathrm{s}$, $\left.-\mathrm{NCOOC}\left(\mathrm{CH}_{3}\right)_{3}\right), 3.06(1 \mathrm{H}, \mathrm{ddd}, \quad J=2.0,4.9$ and $12.5 \mathrm{~Hz}, 3-\mathrm{H}), 3.44(1 \mathrm{H}, \mathrm{t}, J=12.5 \mathrm{~Hz}, 2-\mathrm{Hax}), 3.66(1 \mathrm{H}$, dd, $J=4.9$ and $12.5 \mathrm{~Hz}, 2-\mathrm{Heq}), 4.53(1 \mathrm{H}, \mathrm{dd}, J=2.0$ and $7.3 \mathrm{~Hz}, 5-\mathrm{H}), 4.84(1 \mathrm{H}, \mathrm{dd}, J=2.0,7.3 \mathrm{~Hz}, 4-\mathrm{H})$ and $5.76(1 \mathrm{H}, \mathrm{d}, J=2.0 \mathrm{~Hz}, 6-\mathrm{H})$. Anal. Calcd for $\mathrm{C}_{16} \mathrm{H}_{23} \mathrm{Cl}_{3} \mathrm{~N}_{2} \mathrm{O}_{7}: \mathrm{C} 41.62, \mathrm{H} \mathrm{5.02}, \mathrm{N}$ 6.07. Found: $\mathrm{C}$ 41.40, H 5.24, N 6.24.

(3S,4S,5R,6R)-4,5-Dihydroxy-6-(trichloroacetamido)piperidine-3-carboxylic Acid (4)

Compound $8(32 \mathrm{mg})$ was dissolved in $4 \mathrm{M}$ hydrogen chloride in dioxane $(1 \mathrm{ml})$, and the mixture was stirred at room temperature overnight. The resulting precipitates were collected by centrifugation and washed with $\mathrm{Et}_{2} \mathrm{O}$ to give a colorless amorph solid of $\mathbf{4}$ as its hydrochloride $(25 \mathrm{mg}, 100 \%):[\alpha]_{\mathrm{D}}^{26}+31^{\circ}\left(\mathrm{c} 0.7, \mathrm{H}_{2} \mathrm{O}\right)$; IR $(\mathrm{KBr}) 3500$, $3400,2990,2925,2890$ (sh), 2870, 1735, 1730, 1530, 1460 , $1430,1410,1315,1290,1230,1170,1110,1050$, $1020 \mathrm{~cm}^{-1} ;{ }^{1} \mathrm{H}$ NMR $\left(\mathrm{D}_{2} \mathrm{O}\right) \delta 3.15(1 \mathrm{H}, \mathrm{ddd}, J=2.4$, 8.3 and $9.8 \mathrm{~Hz}, 3-\mathrm{H}$ ), 3.55 and 3.56 (each $1 \mathrm{H}, \mathrm{d}, J=8.3$ and $9.8 \mathrm{~Hz}, 2-\mathrm{H}), 4.22(1 \mathrm{H}$, dd, $J=2.4$ and $10.3 \mathrm{~Hz}, 5-\mathrm{H})$, $4.62(1 \mathrm{H}, \mathrm{t}, J=2.4 \mathrm{~Hz}, 4-\mathrm{H})$ and $5.16(1 \mathrm{H}, \mathrm{d}, J=10.3 \mathrm{~Hz}$, 6-H); FAB-MS (positive) $m / z 320(\mathrm{M}+\mathrm{H})^{+}, 286,160$, $142,110,75$ and 57.

$(2 S, 3 R, 4 S, 5 R)-N$-(tert-Butoxycarbonyl)-2-[N, $N^{\prime}$-di(tert-butoxycarbonyl)]guanidino-3-hydroxymethyl-3,4$O$-isopropylidene-3,4-piperidinediol (9)

To a soln of $6(109 \mathrm{mg})$ in DMF $(2 \mathrm{ml})$ were added triethylamine $(0.2 \mathrm{ml}), \quad N, N^{\prime}$-di-(tert-butoxycarbonyl)thiourea $(199 \mathrm{mg})$ and mercury (II) chloride $(196 \mathrm{mg})$ at $0^{\circ} \mathrm{C}$, and the mixture was stirred at $0^{\circ} \mathrm{C}$ for 2 hours. After addition a large amount of EtOAc, the resulting precipitates were removed by centrifugation. The precipitates were washed with EtOAc. The supernatant and washings were combined, and the soln was washed with water and a satd aq $\mathrm{NaCl}$ soln, dried over $\mathrm{MgSO}_{4}$, and filtered. Evaporation of the solvent gave a solid, which was subjected on column chromatography of silica gel. Elution with a mixture of $\mathrm{CHCl}_{3}$ and $\mathrm{MeOH}(100: 1)$ gave an amorph solid of $9(184 \mathrm{mg}, 94 \%)$ : $[\alpha]_{\mathrm{D}}^{24}+45.6^{\circ}$ (c 0.83, $\mathrm{CHCl}_{3}$ ); IR $\left(\mathrm{CHCl}_{3}\right) 3310,2980,2940,1790$, $1720,1700,1620,1560,1480,1460,1400,1375,1330$, $1290,1255,1235,1210$ (sh), 1170 (sh), 1160, 1120, 1060, $1030,1005 \mathrm{~cm}^{-1} ;{ }^{1} \mathrm{H}$ NMR $\left(\mathrm{CDCl}_{3}, 40^{\circ} \mathrm{C}\right) \delta 1.34$ 
and $1.45(3 \mathrm{H}$, each $\mathrm{s}$, isopropylidene $), 1.45,1.47$ and $1.49\left(9 \mathrm{H}\right.$, each s, $\left.-\mathrm{NCOOC}\left(\mathrm{CH}_{3}\right)_{3}\right), 2.08(1 \mathrm{H}, \mathrm{m}, 5-\mathrm{H})$, $3.21(1 \mathrm{H}, \mathrm{t}, J=12.2 \mathrm{~Hz}, 6-\mathrm{Hax}), 3.50(1 \mathrm{H}$, dd, $J=4.4$ and $12.2 \mathrm{~Hz}, 6-\mathrm{Heq}), 3.7 \sim 3.9\left(2 \mathrm{H}, \mathrm{m},-\mathrm{CH}_{2} \mathrm{OH}\right)$, $4.56(2 \mathrm{H}$, broad s, $3-\mathrm{H}$ and $4-\mathrm{H}), 6.19(1 \mathrm{H}$, broad $\mathrm{d}$, $J=6.4 \mathrm{~Hz}, \quad 2-\mathrm{H}), \quad 8.35(1 \mathrm{H}$, broad $\mathrm{d}, \quad J=6.4 \mathrm{~Hz}$, $-\mathrm{C}\left(\mathrm{NCOOC}\left(\mathrm{CH}_{3}\right)_{3}\right) \mathrm{NH}-$ ) and $11.37(1 \mathrm{H}$, broad s, $-\mathrm{N} H\left(\mathrm{COOC}\left(\mathrm{CH}_{3}\right)_{3}\right)$ ); FAB-MS (positive) $m / \mathrm{z} 545$ $(\mathrm{M}+\mathrm{H})^{+}, 186,148$ and 57 .

$(3 S, 4 S, 5 R, 6 S)-N-($ tert - Butoxycarbonyl $)-6-\left[N, N^{\prime}-\right.$ di(tert-butoxycarbonyl)]guanidino-4,5-dihydroxy-4,5$O$-isopropylidenepiperidine-3-carboxylic Acid (10)

The procedures used for the preparation of $\mathbf{1 0}$ were similar to those used for the preparation of 8 from 7 ; the yields of amorph solid of 10 was $69 \%:[\alpha]_{\mathrm{D}}^{25}+41.3^{\circ}$ (c 0.67, MeOH); IR (KBr) 3420, 3310, 2980, 2940, 1720, $1645,1620,1560,1480,1465,1400,1380,1330,1290$, $1260,1235,1220,1170,1130,1070,1035,1000 \mathrm{~cm}^{-1}$; ${ }^{1} \mathrm{H}$ NMR $\left(\mathrm{CD}_{3} \mathrm{OD}, 40^{\circ} \mathrm{C}\right) \delta 1.35$ and $1.41(3 \mathrm{H}$, each $\mathrm{s}$, isopropylidene), 1.46 and $1.50(27 \mathrm{H}$, each $\mathrm{s}$, $\left.-\mathrm{NCOOC}\left(\mathrm{CH}_{3}\right)_{3} \times 3\right), 2.84(1 \mathrm{H}$, ddd, $J=2.4,4.6$ and $12.7 \mathrm{~Hz}, 3-\mathrm{H}), 3.46(1 \mathrm{H}$, broad t, $J=12.7 \mathrm{~Hz}, 2-\mathrm{Hax})$, $3.68(1 \mathrm{H}, \mathrm{dd}, J=4.6$ and $12.7 \mathrm{~Hz}, 2-\mathrm{Heq}), 4.61(1 \mathrm{H}, \mathrm{dd}$, $J=2.0$ and $7.3 \mathrm{~Hz}, 5-\mathrm{H}), 4.86(1 \mathrm{H}, \mathrm{dd}, J=2.4$ and $7.3 \mathrm{~Hz}$, $4-\mathrm{H})$ and $6.04(1 \mathrm{H}, \mathrm{d}, J=2.0 \mathrm{~Hz}, 6-\mathrm{H})$; FAB-MS (positive) $m / z 559(\mathrm{M}+\mathrm{H})^{+}, 200,148,104$ and 57 .

$(3 S, 4 S, 5 R, 6 R)$-6-Guanidino-4,5-dihydroxypiperidine3-carboxylic Acid (5)

To a soln of 10 in dichloromethane $(0.6 \mathrm{ml})$ was added trifluoroacetic acid $(0.6 \mathrm{ml})$, and the mixture was stirred at room temperature for 8 hours. Evaporation of the solvent gave a solid, which was subjected to column chromatography on Diaion HP20 resin. Elution with water gave an oil, which was solidified by removal of water by azeotropic evaporation with $\mathrm{MeOH}$. The solid was dissolved in a small amount of $\mathrm{MeOH}(50 \mu \mathrm{l})$, and to the soln were added a soln of $4 \mathrm{M}$ hydrogen in dioxane $(1 \mathrm{ml})$ and $\mathrm{Et}_{2} \mathrm{O}(5 \mathrm{ml})$ under vigorously stirring. The resulting precipitates were collected by centrifugation and washed with $\mathrm{Et}_{2} \mathrm{O}$ to give a colorless amorph solid of 5 as its hydrochloride $(19 \mathrm{mg}, 94 \%)$ : $[\alpha]_{\mathrm{D}}^{26}+26.6^{\circ}(c 0.39$, $\mathrm{H}_{2} \mathrm{O}$ ); IR (KBr) 3400, 1720, 1690, 1640 (sh), 1400, 1345, 1285 (sh), 1230 (sh), 1185, 1145, $1100,1030,1010 \mathrm{~cm}^{-1}$; ${ }^{1} \mathrm{H}$ NMR $\left(\mathrm{D}_{2} \mathrm{O}\right) \delta 3.10(1 \mathrm{H}, \mathrm{dt}, J=2.2$ and $8.8 \mathrm{~Hz}, 3-\mathrm{H})$, $3.54(2 \mathrm{H}, \mathrm{d}, J=8.8 \mathrm{~Hz}, 2-\mathrm{H}), 4.01(1 \mathrm{H}, \mathrm{dd}, J=2.2$ and $9.8 \mathrm{~Hz}, 5-\mathrm{H}), 4.60(1 \mathrm{H}, \mathrm{t}, J=2.2 \mathrm{~Hz}, 4-\mathrm{H})$ and $5.04(1 \mathrm{H}$, $\mathrm{d}, J=9.8 \mathrm{~Hz}, 6-\mathrm{H}$ ); FAB-MS (positive) $219(\mathrm{M}+\mathrm{H})^{+}$, $185,152,110,93,75,60$ and 57.

\section{References}

1) NaKaO, H.; K. Takamori \& H. Ogawa: Interaction of tumor and surrounding tissue of mice inoculated B16 melanoma variants in terms of enzyme activity. Int. $\mathbf{J}$. Biochem. 21: 739 743, 1989

2) Twijnstra, A.; B. W. Ongeboer de Visser, A. P. van Zanten, A. A. M. Hart \& W. J. NoOYen: Serial lumbar and ventricular cerebrospinal fluid biochemical marker measurements in patients with leptomeningeal metastases from solid and hematological tumors. J. Neuro-oncol. 7: $57 \sim 63,1989$

3) Keren, Z.; F. Leland, M. Nakajima \& S. J. LeGrue: Inhibition of experimental metastasis and extracellular matrix degradation by butanol extracts from B16-F1 murine melanoma. Cancer Res. 49: 295 300, 1989

4) Nakajima, M.; K. Morikawa, A. Fabra, C. D. Bucana \& I. J. FIDLER: Influence of organ environment on extracellular matrix degradative activity and metastasis of human color carcinoma cells. J. Natl. Cancer Inst. 82: $1890 \sim 1898,1990$

5) JiN, L.; M. NAKaJima \& G. L. NiColson: Immunochemical localization of heparanase in mouse and human melanomas. Int. J. Cancer 45: $1088 \sim 1095,1990$

6) Nishimura, Y.; W. Wang, S. Kondo, T. Aoyagi \& H. UMEZAWA: Siastatin B, a potent neuraminidase inhibitor: the total synthesis and absolute configuration. J. Am. Chem. Soc. 110: $7249 \sim 7250,1988$

7) Nishimura, Y.; W. Wang, T. Kudo \& S. Kondo: Total synthesis of siastatin $B$ and its enantiomer using carbohydrate as a chiral educt. Bull. Chem. Soc. Jpn. 65: $978 \sim 986,1992$

8) Kudo, T.; Y. Nishimura, S. Kondo \& T. Takeuchi: Totally synthetic analogues of siastatin B. I. Optically active 2-acetamidopiperidine derivatives. I. Antibiotics 45: $954 \sim 962,1992$

9) Nishimura, Y.; T. Kudo, S. Kondo \& T. Takeuchi: Totally synthetic analogues of siastatin B. II. Optically active piperidine derivatives having trifluoroacetamide and hydroxyacetamide groups at C-2. J. Antibiotics 45: $963 \sim 970,1992$

10) Nishimura, Y.; T. Kudo, Y. UmeZawa, S. Kondo \& T. TAKEUCHI: Design of potential neuraminidase inhibitors by dehydration, deoxygenation and epimerization of siastatin B. Natural Prod. Lett. 1: 39 44, 1992

11) Nishimura, Y.; T. Kudo, Y. UmeZawa, S. Kondo \& T. TAKEUCHI: Potent inhibition of neuraminidase by $N$-(1,2-dihydroxypropyl) derivatives of siastatin B and its analogs. Natural Prod. Lett. 1: 33 38, 1992

12) Kudo, T.; Y. Nishimura, S. Kondo \& T. Takeuchi: Syntheses and activities of $N$-substituted derivatives of siastatin B. J. Antibiotics 45: 1662 1668, 1992

13) Kudo, T.; Y. Nishimura, S. Kondo \& T. Takeuchi: Syntheses of the potent inhibitors of neuraminidase, $N$-(1,2-dihydroxypropyl) derivatives of siastatin B and its 4-deoxy analogs. J. Antibiotics 46: 300 309, 1993

14) Nishimura, Y.; Y. UmeZawa, S. Kondo, T. TAKeUdChi, K. Mori, I. Kujima-Suda, K. Tomita, K. Sugawara \& K. Nakamura: Synthesis of 3-episiastatin B analogues having anti-influenza virus activity. J. Antibiotics 46: $1883 \sim 1889,1993$

15) Nishimura, Y; T. Kudo, S. Kondo, T. Takeuchi, T. Tsuruoka, H. Fukuyasu \& S. Shibahara: Totally synthetic analogues of siastatin B III. Trifluoroacetamide analogues having inhibitory activity for tumor metastasis. J. Antibiotics 47: $101 \sim 107,1994$

16) Nishimura, Y.; S. Satoh, S. Kondo, T. Takeuchi, M. Azetaka, H. Fukuyasu, Y. Iizuka \& S. Shibahara: Effect on spontaneous metastasis of mouse Lewis lung carcinoma by a trifluoroacetamide analogue of siastatin B. J. Antibiotics 47: $840 \sim 842,1994$ 
17) Umezawa, H.; T. Aoyagi, T. Komiyama, H. Morishima, M. HAMADA \& T. TAKEUCHI: Purification and characterization of a sialidase inhibitor, siastatin, produced by Streptomyces. J. Antibiotics 27: $963 \sim 969,1974$

18) Satoh, T.; Y. Nishimura, S. Kondo \& T. TakeUchi: A practical synthesis of $(3 S, 4 S, 5 R, 6 R)$-4,5-dihydroxypiperidine-6-(trifluoroacetamido)-3-carboxylic acid, an inhibiting agent for experimental and spontaneous pulmonary metastasis of tumor cells. Carbohyd. Res., in press

19) Carson, P. H.; T. Katsuki, V. S. Martin \& K. B. SHARPLESS: A greatly improved procedure for ruthenium tetraoxide catalyzed oxidations of organic compounds. $\mathbf{J}$. Org. Chem. 46: 3936 3938, 1981

20) KIM, K. S. \& L. QIAN: Improved method for preparation of guanidines. Tetrahedron Lett. 34: 7677 7680, 1993

21) FidLER, I. J.: Biological behavior of malignant melanoma cells correlated to their survival in vivo. Cancer Res. 35 : $218 \sim 224,1975$

22) Tsuruoka, T; H. Fukuyasu, M. Azetaka, Y. Iizuka,
K. Kawarajo, S. Inouye, M. Hosokawa \& $\mathrm{H}$. KOBAYASHI: Inhibition of pulmonary metastases in experimental tumor by D-glucaro- $\delta$-lactam sodium salt. The Second Joint Meeting of the American Association of Cancer Research and the Japanese Cancer Association, abstr. B-3, Hawaii, 1992

23) Irimura, T.; M. NakaJima \& G. L. Nicolson: Chemically modified heparins as inhibitors of heparan sulfate specific endo-beta-glucuronidase (heparanase) of metastatic melanoma cells. Biochemistry 25: 5322 5328, 1986

24) Nakajima, M.; T. Irimura \& G. L. Nicolson: Heparanase and tumor metastasis. J. Cell Biochem. 36: $157 \sim 167,1988$

25) Halvorson, H. O. \& L. Ellias: Purification and properties of an $\alpha$-glucosidase of Saccharomyces italicus Y1225. Biochim. Biophys. Acta 30: $28 \sim 40,1958$

26) STAHL, P. D. \& O. TOUSTER: $\beta$-Glucuronidase of rat liver lysosomes. Purification, properties, subunits. J. Biol. Chem. 246: $5398 \sim 5406,1971$ 